\title{
New locality record of Lacerta agilis (Squamata: Lacertidae) in Turkey
}

\author{
Lacerta agilis (Squamata: Lacertidae)'in Türkiye'deki yeni lokalite kaydı \\ Ufuk BÜLBÜL $\odot$, Halime KOç* ${ }^{*}$, Hatice ÖZKAN $\odot$, insan ÖZTÜRK $\odot$, Bilal KUTRUP $\odot$ \\ Department of Biology, Faculty of Science, Karadeniz Technical University, Trabzon, Turkey
}

\section{Article Info}

(C2018 Ali Nihat Gökyiğit Botanical Garden Application and Research Center of Artvin Çoruh University.

*Corresponding author:

e-mail: koc.halime@gmail.com

ORCID: 0000-0003-2998-4384

\section{Article history}

Received: July 24, 2019

Received in revised form: September 16, 2019

Accepted: September 17, 2019

Available online: September 20, 2019

\section{(c) (1)} article under the CC BY license (http://creativecommons.org/licenses /by/4.0/).

\begin{abstract}
In this study, it was given the locality record of the sand lizard (Lacerta agilis) from Yeşilköy Village, Pazar District of Rize Province of Turkey. This new record revealed the second locality for L. agilis from the eastern Black Sea coast of Anatolia. The metric and meristic features of the adult, subadult and juvenile specimens were compared to the features of the specimens of the species, L. agilis in the literature.
\end{abstract}

\section{Öz}

Bu çalışmada, Kars kertenkelesi (Lacerta agilis)'in Türkiye'de Rize ilinin Pazar ilçesinin Yeşilköy köyünden lokalite kaydı verilmiştir. Bu yeni kayıt L. agilis türünün Anadolu'nun Doğu Karadeniz kısmındaki ikinci lokalite kaydını oluşturmaktadır. Ergin, yarı ergin ve juvenile bireylerin metric ve meristic özellikleri literatürde L. agilis türünün bireylerinin özellikleriyle karşılaştırılmıştır.

Keywords:

Sand lizard, pholidosis, morphometric, Pazar, Rize.

Anahtar kelimeler:

Kars kertenkelesi, folidosis, morfometrik, Pazar, Rize.

\section{Citation:}

To cite this article: Bülbül U, Koç H, Özkan H, Öztürk i, Kutrup B (2019). New locality record of Lacerta agilis (Squamata: Lacertidae) in Turkey. Turk J Biod 2(2): 52-56.

\section{INTRODUCTION}

The Sand lizard, Lacerta agilis shows extensive distribution including 45 countries in the world. It is distributed in Europe, Moldova, Latvia, Estonia, Lithuania, Belarus, Russia, Ukrain, Georgia, Turkey, Armenia, Azerbaijan, Kazakhstan, Kyrgyzstan, China and Mongolia (Agasyan et al., 2010; Uetz et al., 2013).

Although L. agilis is found in a great range of habitats, and is still abundant in many countries, it has suffered massive population declines along the northwestern edge of its world range (Edgar \& Bird, 2005). The IUCN Red List of Threatened Species classifies this lizard at LC (Least Concern) category since 2009.

L. agilis has ten subspecies. Only two of them ( $L$. $a$. brevicaudata and L. a. grusinica) have distribution areas in Turkey.
L. a. brevicaudata was recorded around Erzurum, Ardahan and Kars Provinces (Mertens, 1952; Clark \& Clark, 1973; Başoğlu \& Baran, 1977; Mulder, 1995; Baran et al., 2012). In Turkey, L. a. grusinica was only recorded from Hopa district of Artvin Province (Mulder, 1995). Although two specimens of $L$. agilis from Khost (Coşandere) locality in Trabzon Province were evaluated belonged to the subspecies of $L$. $a$. grusinica by Peters (1962), this publication was refuted by Schmidtler (1986). The recommendations of Başoğlu and Baran (1977) and Kalyabina-Hauf and Ananjeva (2004) pointing out that this subspecies could spread from Trabzon to the eastern parts of Black Sea in Turkey, are need to be verified. It is still unclear some points of distribution of $L$. $a$. grusinica on the Black Sea coast (Tuniyev \& Tuniyev, 2008).

The present study provides a new locality record of $L$. agilis in Rize Province of Turkey. Some metric and meristic 
characteristics of the L. agilis specimens captured from this locality were presented.

\section{MATERIAL AND METHOD}

During two field studies on $14^{\text {th }}$ and $27^{\text {th }}$ April 2019, 1 adult $\sigma^{\prime \prime} \sigma^{\prime \prime}, 2$ subadult $\% \circ$ and 5 juvenile individuals of Lacerta agilis grusinica were recorded from Yeşilköy Village, Pazar District of Rize Province $\left(41^{\circ} 09^{\prime} 900^{\prime \prime} \mathrm{N}\right.$, $40^{\circ} 50^{\prime} 477^{\prime \prime} \mathrm{E}, 182 \mathrm{~m}$ a.s.l.). A map indicating the new locality is given in Figure 1 . We photographed the individuals in their natural habitat and the lizards were anesthetized by MS 222. After we injected a $10 \%$ formaldehyde solution, the lizards were stored in $70 \%$ ethanol. The collection numbers (KZL-343 and KZL-348 for Yeşilköy) were given to the specimens and they were stored at the Karadeniz Technical University, Department of Biology, Zoology Research Laboratory.

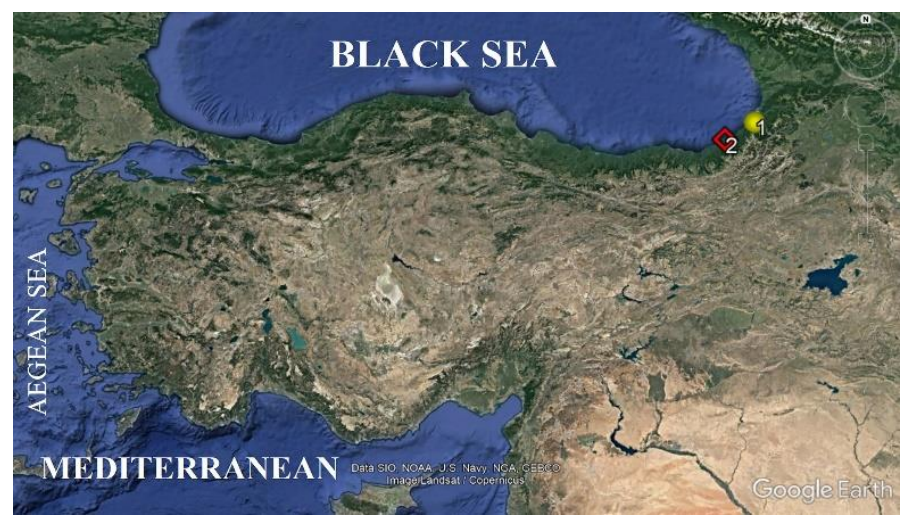

Figure 1. Map showing the locality of $L$. a. grusinica in Turkey. 1. Hopa, Artvin; 2. Yeşilköy, Pazar-Rize (The red colored diamond shows the new locality).

We obtained the pholidolial and morphometric data modifying the data of Peters (1960), Peters (1962) and Schmidtler (1986). For morphological observations, a stereomicroscope was used. To measure the morphometric features to the nearest to $0.01 \mathrm{~mm}$, a digital caliper was used. We compared our results with the data obtained from the researches of Peters (1960), Peters (1962) and Schmidtler (1986). The assessed pholidolial features were: supraciliar granules (right-left, SCGa-SCGb), supraciliar plates (right-left, SCPa-SCPb), supralabials (right-left, SRLa-SRLb, number of labials both anterior and posterior to center of eye), sublabials (right-left, SLPa-SLPb), collar (C), ventral plates (transversal and longitudinal, TVP and LVP), femoral pores (right-left, $\mathrm{FPa}-\mathrm{FPb}$ ), transversal series of dorsal scales at the midbody (DS), number of preanal scales surrounding anals (PA1) and all plates surrounding anals
(PA2), formula for postnasal + frenal plates $(P+F)$, preocular plates (PreO), the number of subdigital lamalleae under the $4^{\text {th }}$ toe (SDL), the number of plates between tympanium and supratemporal (T-S), temporalia $(T)$, and gularia $(G)$.

The metric characteristics used in the present study are: snout-vent length (SVL), tail length ( $T L)$, pileus width $(P W)$, pileus length (PL), head width (HW), head length $(H L)$, total body length (TBL), and hind limb length (HLL).

\section{RESULTS}

The vegetation of the habitat of the specimens from Rize, Yeşilköy generally comprises tea plants (Figure 2). Darevskia derjugini (Nikolsky, 1898) Darevskia rudis (Bedriaga, 1886) and Anguis fragilis (L., 1758) live in sympatry in the study area. We performed the sampling in two day excursions between $12.00-14.30$ hours on 14th April 2019 and 11.00-17.00 hours on 27th April 2019. The air temperatures were 19 and $16^{\circ} \mathrm{C}$, respectively.

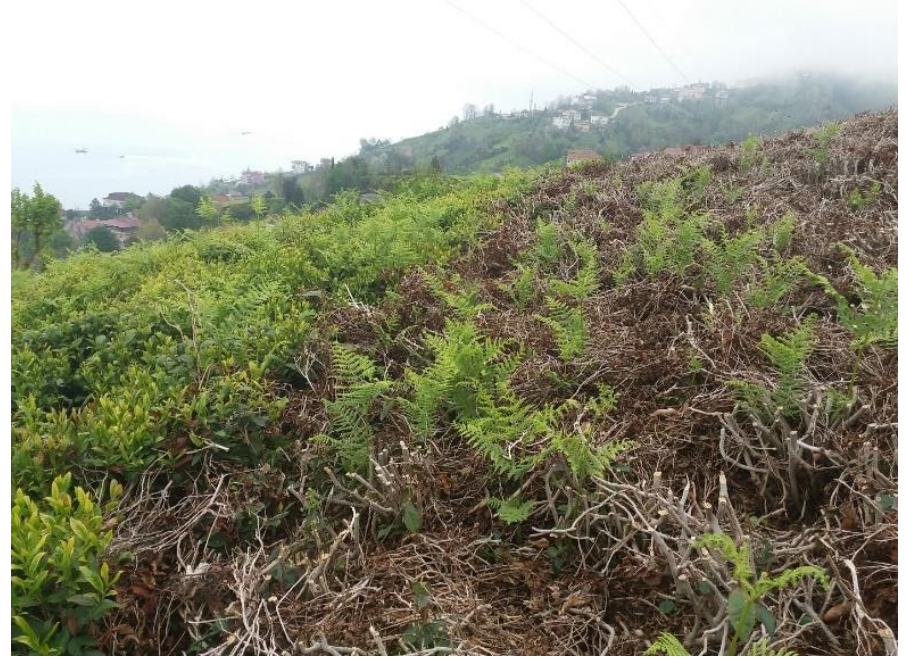

Figure 2. Habitat of L. a. grusinica from Yeşilköy, PazarRize.

\subsection{Examined Specimens}

Lacerta agilis: Turkey, Rize, Pazar, Yeşilköy, KZL343/2019, 2 juveniles 04.14.2019; KZL-348/2019 1 adult

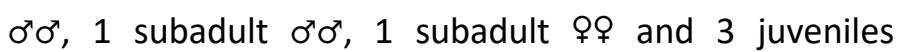
04.27.2019, leg. U. BÜLBÜL, H. ÖZKAN, and I. ÖZTÜRK, KTU, TRABZON

\subsection{Pholidolial characteristics}

Rostrals and internasals were separated in all specimens. SCPa and SCPb were 5 in all observed lizards. SRLa and SRLb was found 7 in all specimens. SLPa was $6(12.5 \%)$ in 1 specimen and 7 (87.5\%) in 7 specimens while $6 \mathrm{SLPb}$ was 
found in all specimens. DS of the specimens was small and smooth. PA1 was 2 in all specimens while PA2 was 6 in most of the specimens (75\%) and it was rarely 7 (25\%).

\subsection{Morphometric measurements}

TBL was $235.9 \mathrm{~mm}$ in the adult male specimen, 151.67 $\mathrm{mm}$ in the subadult male specimen and $143.03 \mathrm{~mm}$ in the subadult female specimen. The maximum TBL was 126.83 $\mathrm{mm}$ for juveniles. SVL was 91.9 in the adult male, 60.12 $\mathrm{mm}$ in the subadult male and $56.81 \mathrm{~mm}$ in the subadult female. The maximum SVL was $51.94 \mathrm{~mm}$ for juveniles. Some of the metric and meristic features of the specimens caught from Yeşilköy, Rize are given in Table 1.

\subsection{Color pattern}

In the adult male specimen, the head was dark greenbrownish. The sides of the head were light green. There were black spots on the supralabial and sublabial plates. Middle of the dorsum and limbs were light green. There were small black spots on the lateral of the dorsum and on the limbs. The tail had a brown color on green back - ground. The ventral was greenish and there were dark spots on the ventral plates (Figure 3).

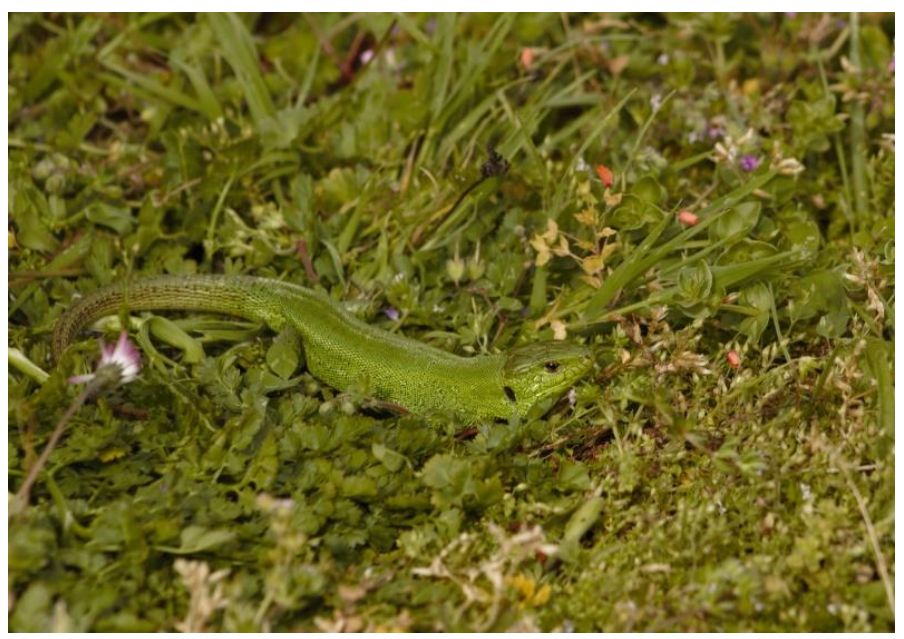

Figure 3. The male specimen of L. a. grusinica from Yeşilköy population.

Table 1. Some metric and meristic features of Lacerta agilis grusinica specimens collected from Yeşilköy population. For abbreviations see text.

\begin{tabular}{|c|c|c|c|c|c|c|c|c|c|c|c|c|c|}
\hline \multirow[b]{2}{*}{ Characters } & \multicolumn{2}{|c|}{$\begin{array}{l}\text { Peters } \\
(1960)\end{array}$} & \multicolumn{2}{|c|}{$\begin{array}{l}\text { Peters } \\
(1962) \\
\end{array}$} & \multirow{2}{*}{$\begin{array}{c}\begin{array}{c}\text { Schmidtler } \\
\text { (1986) }\end{array} \\
7 \text { Adults } \\
\text { (Mean) }\end{array}$} & \multicolumn{8}{|c|}{ This study } \\
\hline & $\begin{array}{l}19 \\
\text { 우우 }\end{array}$ & 18 & $\begin{array}{c}1 \\
q ㅇ\end{array}$ & 1 & & 1 adult & $\begin{array}{c}1 \\
\text { subadult } \\
\varnothing q\end{array}$ & $\begin{array}{c}1 \\
\text { subadult } \\
\partial^{\lambda} \delta^{\lambda}\end{array}$ & $\begin{array}{c}1 . \\
\text { Juv. }\end{array}$ & $\begin{array}{c}2 . \\
\text { Juv. }\end{array}$ & $\begin{array}{l}3 . \\
\text { Juv. }\end{array}$ & $\begin{array}{c}4 . \\
\text { Juv. }\end{array}$ & $\begin{array}{c}5 . \\
\text { Juv. }\end{array}$ \\
\hline SCPa- $\mathrm{SCPb}$ & - & - & - & - & $5.2-5.2$ & $5-5$ & $5-5$ & $5-5$ & $5-5$ & $5-5$ & $5-5$ & $5-5$ & $5-5$ \\
\hline SRLa- SRLb & - & - & - & - & - & $7-7$ & $7-7$ & $7-7$ & $7-7$ & $7-7$ & $7-7$ & $7-7$ & $7-7$ \\
\hline SLPa- SLPb & - & - & 5 & 5 & - & $7-6$ & $6-6$ & $6-6$ & $6-6$ & $6-6$ & $6-6$ & $6-6$ & $6-6$ \\
\hline $\mathrm{C}$ & - & - & - & - & 12.1 & 11 & 11 & 10 & 10 & 11 & 10 & 11 & 11 \\
\hline TVP & $27-30$ & $24-28$ & 27 & 26 & - & 27 & 29 & 31 & 33 & 29 & 29 & 28 & 29 \\
\hline LVP & - & - & 6 & 6 & - & 6 & 6 & 6 & 6 & 6 & 6 & 6 & 6 \\
\hline $\mathrm{FPa}-\mathrm{FPb}$ & $12-18$ & $12-18$ & $17-17$ & $\begin{array}{l}17- \\
17 \\
\end{array}$ & $15.4-15.4$ & 14-14 & $15-13$ & $15-13$ & $15-13$ & 16-15 & $15-15$ & $\begin{array}{l}15- \\
16 \\
\end{array}$ & 15-14 \\
\hline DS & $44-53$ & $44-54$ & $48-50-52$ & 49 & 48.9 & 58 & 48 & 52 & 55 & 53 & 53 & 52 & 42 \\
\hline PA1 & - & - & 1.66 & 1.82 & - & 2 & 2 & 2 & 2 & 2 & 2 & 2 & 2 \\
\hline PA2 & - & - & - & - & 5.7 & 7 & 6 & 6 & 6 & 6 & 7 & 6 & 6 \\
\hline $\mathrm{P}+\mathrm{F}$ & - & - & $2+0: 2+1$ & $\begin{array}{l}2+1: \\
2+1\end{array}$ & - & $\begin{array}{c}2+1: 2+ \\
1\end{array}$ & $1+1: 1+1$ & $2+1: 2+1$ & $\begin{array}{c}2+1: 2+ \\
1\end{array}$ & $\begin{array}{c}2+1: 2+ \\
1\end{array}$ & $\begin{array}{c}1+1: 2+ \\
1\end{array}$ & $\begin{array}{l}2+1: \\
2+1\end{array}$ & $\begin{array}{c}2+1: 2+ \\
1\end{array}$ \\
\hline PreO & - & - & - & - & 1.9 & $2-2$ & $2-2$ & $2-2$ & $2-2$ & $2-2$ & $2-2$ & $2-2$ & $2-2$ \\
\hline SDL & - & - & 25 & 24 & 22.9 & 24 & 24 & 24 & 24 & 28 & 24 & 28 & 24 \\
\hline T-S & - & - & - & - & 15.3 & 16-14 & $14-16$ & $14-16$ & $17-18$ & $15-16$ & $14-15$ & $\begin{array}{l}14- \\
14 \\
\end{array}$ & 14-14 \\
\hline $\mathrm{T}$ & - & - & - & - & 21.4 & 21 & 21 & 21 & 23 & 22 & 23 & 23 & 23 \\
\hline G & - & - & - & - & 21.3 & 17 & 19 & 19 & 19 & 19 & 19 & 19 & 19 \\
\hline SVL & 90.0 & 85.5 & 105.0 & 82.5 & - & 91.92 & 56.81 & 60.12 & 51.94 & 51.12 & 46.40 & 36.65 & 34.31 \\
\hline TL & - & - & 17 & - & - & 143.98 & 86.20 & 91.55 & 74.89 & 74.33 & 74.31 & 88.13 & 79.65 \\
\hline PW & - & - & - & - & - & 12.09 & 7.35 & 7.05 & 6.76 & 6.92 & 7.49 & 6.97 & 5.04 \\
\hline PL & - & - & 2.13 & 2.10 & - & 2.13 & 1.32 & 1.38 & 1.22 & 1.17 & 1.17 & 1.13 & 0.80 \\
\hline HW & - & - & - & - & - & 18.58 & 9.68 & 9.84 & 8.03 & 7.80 & 7.71 & 8.06 & 7.61 \\
\hline HL & - & - & - & - & - & 32.68 & 19.13 & 19.52 & 16.80 & 16.75 & 16.70 & 13.25 & 10.96 \\
\hline TBL & 23.3 & 23.4 & - & - & - & 23.59 & 14.30 & 15.16 & 12.68 & 12.54 & 12.07 & 12.47 & 11.4 \\
\hline HLL & - & - & 4.70 & 4.45 & - & 4.09 & 2.78 & 2.84 & 2.65 & 2.58 & 2.53 & 2.54 & 2.46 \\
\hline $\begin{array}{l}\text { PL } \times 100 \\
\text { SVL }\end{array}$ & 21.48 & 24.07 & - & - & - & 23.26 & 23.28 & 23.08 & 23.62 & 22.96 & 25.40 & 30.94 & 23.08 \\
\hline
\end{tabular}


The subadult specimens had brown dorsalium except the head and neck. Dorsal and lateral parts of the body had black spots. These spots were bigger on the mid-dorsal. There were three green lines on the dorsal. The lateral part of the body had white spots in three rows. These spots continued from the front of the tympanium to the tail in the upper row, while they ended at the hind limb in the second and third rows. The ventral of the head was green while ventral of other parts of the body were cream colored (Figure 4).

The juveniles had brown dorsalium. As in subadults, dorsal and lateral parts of the body had black spots. These spots were also bigger on the mid-dorsal of juveniles. The three lines on the dorsal were light brown. The characteristics of the white spots on the lateral side were similar to those of the subadults. The ventral was completely cream colored (Figure 4).

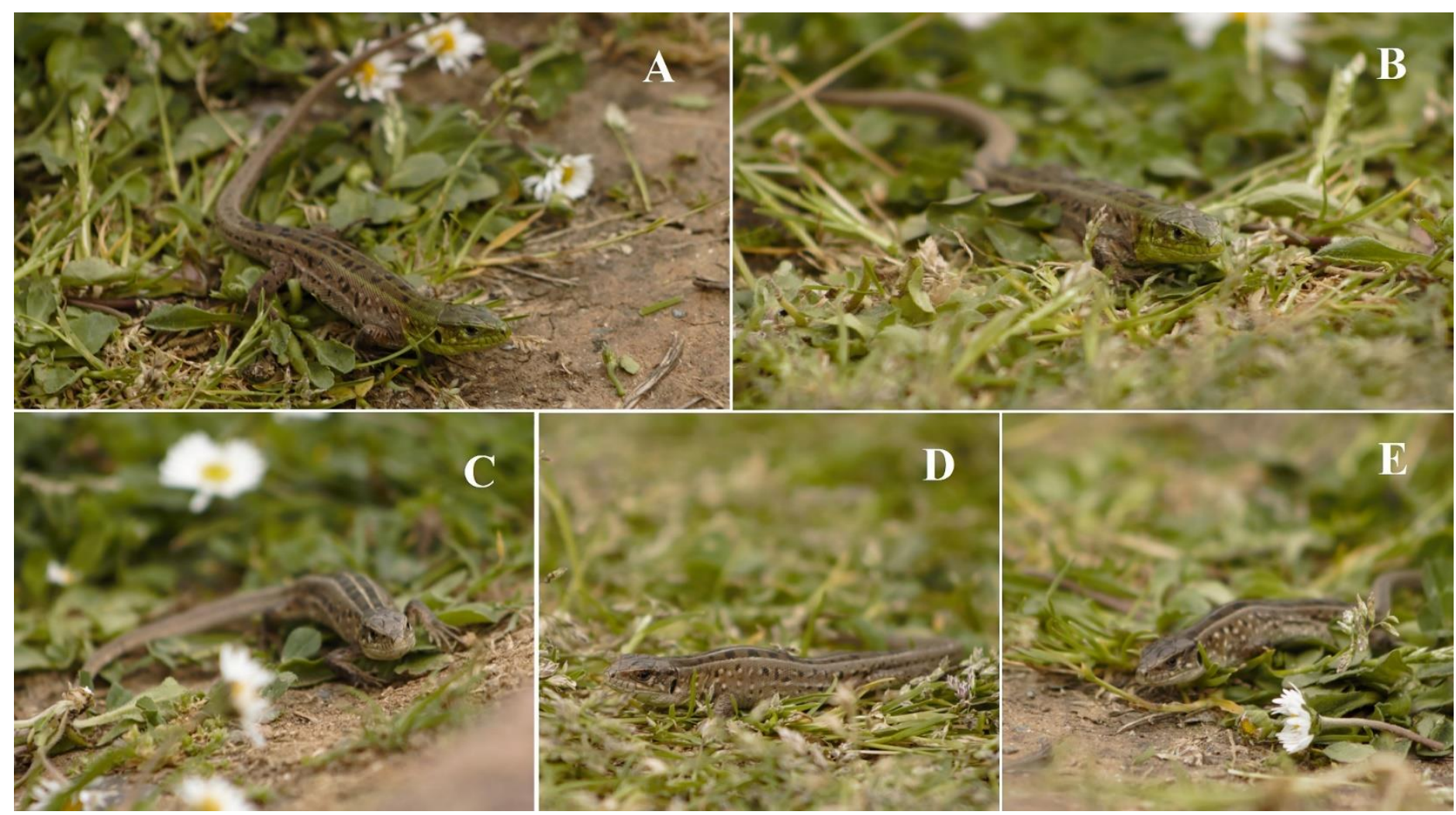

Figure 4. A general view of the subadult and juvenile specimens of $L$. a. grusinica in the studied population. A. subadult 우, B. subadult $\sigma^{\top} \sigma^{\top}, C$. first juvenile, D. second juvenile and E. third juvenile individuals.

\section{DISCUSSION}

Morphological features and metric characteristics of our specimens in the Yeşilköy population were found similar to individuals of $L$. a. grusinica used in the researches of Peters (1960), Peters (1962), and Schmidtler (1986), except slightly lower number of gularia in specimens of the present study. Overlapping postnasal plate number $(2 / 0)$ in our specimens was found similar to those of specimens in the study of Bischoff (1988).

According to the comparison of data given in the literature to our data, we evaluated that the individuals in the Yeşilköy population belong to subspecies of $L$. $a$. grusinica. We reported the first locality record of $L$. $a$. grusinaca for Rize province. The occurrence of the subspecies from Artvin province (in Hopa district) was reported by Mulder (1995). The findings of the present study indicate that the individuals of the subspecies can be found in other suitable habitats in Turkey.

\section{Acknowledgments}

The authors wish to thank Hayri Bülbül for his helping in the field.

\section{REFERENCES}

Baran I, Ilgaz Ç, Avcı A, Kumlutaş Y, Olgun K (2013). Türkiye Amfibi ve Sürüngenleri. Ankara: TÜBITAK Popüler Bilim Kitapları, 204 p. 
Başoğlu M, Baran I (1977). Türkiye Sürüngenleri, Kısım 1. Kaplumbağa ve Kertenkeleler. İzmir: Ege Üniversitesi Fen Fakültesi Kitaplar Serisi No: 76, ilker Matbaası, 272 p.

Bischoff W (1988). Zur verbreitung und systematik der zauneidechse, Lacerta agilis Linnaeus, 1758. Mertensiella 1: 11-30.

Clarck RJ, Clarck ED (1973). Report on a collection of amphibians and reptiles from Turkey. California Academy of Science San Francisco 104: 1-62.

Edgar P, Bird DR (2005). Action plan for the conservation of the Sand Lizard (Lacerta agilis) in Northwest Europe. Strasbourg: Convention on the conservation of European wildlife and natural habitats.

IUCN (2010). The IUCN Red List of Threatened Species. Version 20192. http://dx.doi.org/10.2305/IUCN.UK.20104.RLTS.T157288A5071439.en. Downloaded on 30 May 2019.

Kalyabina-Hauf SA, Ananjeva NB (2004). Phylogeny and intraspecific structure of broad distributed species of lizards Lacerta agilis L.,1758 (Lacertidae, Sauria, Reptilia), St.Petersburg.
Mertens R (1952). Amphibien und reptilien aus der Turkei. Review of Faculty of Science, University of Istanbul, Seri B 17: 41-75.

Mulder J (1995). Herpetological observations in Turkey (1987-1995). Deinsea 2: 51-66.

Peters G (1960). Die Grusinische zauneidechse Lacerta agilis grusinica nomen novum. Zoologischer Anzeiger 165(7/8): 279-289.

Peters G (1962). Studien sur taxionomie, verbreitung und oekologie der smaragdeidechsen. I. Lacerta trilineata, viridis und strigata als selbstaendige Arten. Mitteilungen Zoologisches Museum Berlin 38: 127-152.

Schmidtler JF (1986). Orientalische smaragdeidechsen: 1. Zur systematik und verbreitung von Lacerta viridis in der Türkei (Sauria: Lacertidae). Salamandra 22: 29-46.

Tuniyev SB, Tuniyev BS (2008). Intraspecific variation of the Sand lizard (Lacerta agilis) from the Western Caucasus and description of a new subspecies Lacerta agilis mzymtensis ssp. nov. (Reptilia: Sauria). Russian Journal of Herpetology 15(1): 55-66.

Uetz P, Freed P, Hošek J (2013). The Reptile Database. http://www.reptile-database.org. Downloaded on 16 May 2019. 